Tropical Agricultural Research \& Extension 18 (4): 2015

\title{
JOB SATISFACTION OF EXTENSION OFFICERS: A CASE STUDY IN A PRIVATE ORGANIZATION
}

\author{
SD Widisinghe and AL Sandika* \\ Department of Agricultural Economics and Extension, Faculty of Agriculture, University of Ruhuna, \\ Mapalana, Kamburupitiya, Sri Lanka
}

Accepted: $31^{\text {st }}$ January 2017

\begin{abstract}
Involvement of private sector for agricultural extension is reported to be improved gradually in Sri Lanka over last three decades. However, the effectiveness of extension depends on the job satisfaction (JS) of the extension officers (EOs). Therefore, a survey was conducted in this study with product development officers (PDOs) of a private extension company to evaluate job satisfaction of the EOs and to make appropriate suggestions to improve the JS. Data were collected using a structured questionnaire. All PDOs (total population) (25) were participated for data collection. Based on the Frederick Herzberg two factors motivation theory, developed satisfaction index was used to measure the level of satisfaction. Collected data were analysed using descriptive statistics and Wilcoxon sign rank test. The findings of the study showed that the PDOs are satisfied with working environment, work responsibilities, available teaching material such as leaflets while they are dissatisfied with rewords, fuel and telephone bill allowances, and job security. With regard to overall job satisfaction, majority (76\%) were at the indifferent level. It means that they are neither satisfied or dissatisfied level related to their job.
\end{abstract}

Key words: Job satisfaction, Job security, Working conditions

\section{INTRODUCTION}

Sri Lanka is now gradually introducing feelevying private extension services among commercial farmers with a better ability to pay. It is providing an opportunity to government extension services to serve the poor and subsistence-level groups of farmers more effectively Private sector extension services are integrated with other commercial operations, such as the sale of farm inputs.

Cooperate sector at present in Sri Lanka engage on extension activities as free of charge for farmers. However, the ultimate goal is popularizing or to sell their products and services to the respective farmers through free extension services. Product Development Officers (PDOs) are working as an extension officers. They look at farmers' technical needs and discuss their problems with them and make awareness on plant protection measures PDOs have to perform several duties under their job description. They need to increase the no of 'mega farmers' (large scale cultivation) and "GroMore" farmers (encourage farmers to cultivate more) and make them aware of products through farmer training activities, pocket meetings, demonstrations, Yaya programme and field days.

The job satisfaction (JS) is a popular study area and topic of human resource management. Job satisfaction has been viewed as an interesting concept, but today it is seen as a very complex cluster of attitudes towards different aspects of the work (Rollinson et al., 1998). JS has been closely related with performance, motivation, attitude, leadership, conflict and moral of employees of any organization, (Judge et al., 2001).

*Corresponding author: sandika@agecon.ruh.ac.lk 
The performance of extension works at the field is directly affected by JS of PDOs and it helps to achieve the goals of organization. Under this background, this study was conducted to evaluate JS of the PDOs and to provide appropriate suggestions to improve the JS.

\section{METHODOLOGY}

The descriptive research design was employed for the study. The selected participants were the PDOs in private extension company which was selected purposively. The researchers have formally agreed with the company to keep it name secretly. The data were collected from Kurunagala, Anuradhapura, Polonaruwa, Rathnapura, Batiicaloa, Ampara, Monaragala, Hambanthota, Matara and Galle districts. Since the small population all of the PDOs 25 were selected to collect the data. Data were collected by using structured questionnaire and interview method.

In this research, satisfaction about working condition, rewards, job facilities, relationship with supervisor, job security and satisfaction about balance between family life and career life were measured based on Likert-scale with five points scale where -1 represents "very dissatisfied" and 5 represents "very satisfied". Job satisfaction score of a respondent was obtained by summing up the scores obtained by him on all the statements. Further, respondents were classified into three categories such as satisfied, indifferent and dissatisfied based on mean and variance value of JS. The collected data were further analysed by using descriptive statistics and Wilcoxon sign rank test.

\section{RESULTS AND DISCUSSION}

Respondents highly satisfied about the work environment and it has significant impact on job satisfaction. These findings were supported by Hong et al (2013). Safe working condition was not significantly impacted on job satisfaction. Respondents are in the satisfactory level about their working responsibilities and there is significant between working responsibilities and the job satisfaction. However, respondents are in the dissatisfactory level about their salary. Salary displays a significant relationship with the level of job satisfaction. The result was consistent with Wubuli's (2009). Further, he pointed out that hygiene factors like salary is a significant predictor of job satisfaction. Therefore, the salary has affected employees' job satisfaction. There was no significant relationship between incentives and the level of job satisfaction. There was no significant relationship between promotion and the job satisfaction. Respondents dissatisfy about fuel and telephone bill allowances. Further, there is a significant relation between fuel and telephone bill allowances with job satisfaction. Respondents highly satisfy about available teaching aids such as "Gro More" books, flipcharts, and leaflets. Respondents are in the highly satisfy level with the supervisor relationship. The relationship with the supervisor has a significant impact to job satisfaction. Respondents are very satisfy with the continuous feedback given by the supervisors. The result showed that supervisors' feedback has a significant impact on job satisfaction. Respondents dissatisfy about the job security and there is significant relationship between job security and the job satisfaction.

The overall job satisfaction of PDOs has been measured by using satisfaction index which was developed by Brayfield and Rothe (1951) and used in the previous studies. With regard to overall job satisfaction, majority $(76 \%)$ are at the indifferent level. It means that majority are neither satisfied nor dissatisfied level.

Further, only $24 \%$ of respondents are in satisfactory level regarding their job. Moreover, the study further showed that no one in unsatisfied level about their job. Table shows the satisfaction level of different criteria which were considered related to JS of the respondents. Similar result found by Sandika and De Silva (2012) for their study on Relationship between job satisfaction and organizational climate: The 
Table 1. PDOs satisfaction about different criteria

\begin{tabular}{|c|c|c|c|c|c|c|c|c|}
\hline Criteria & +2 & +1 & 0 & -1 & -2 & $\begin{array}{l}\text { Mean } \\
\text { Value }\end{array}$ & $\begin{array}{l}\mathrm{P} \\
\text { Value }\end{array}$ & Results \\
\hline \multicolumn{9}{|c|}{ Satisfaction about the working condition. } \\
\hline $\begin{array}{l}\text { I am satisfied with } \\
\text { the working } \\
\text { environment of the } \\
\text { company. }\end{array}$ & $\begin{array}{l}8 \\
(32 \%)\end{array}$ & $\begin{array}{l}16 \\
(64 \%)\end{array}$ & $\begin{array}{l}1 \\
(4 \%)\end{array}$ & $\begin{array}{l}0 \\
(0 \%)\end{array}$ & $\begin{array}{l}0 \\
(0 \%)\end{array}$ & 1.28 & 0.00 & $\begin{array}{l}\text { Highly } \\
\text { satisfied }\end{array}$ \\
\hline $\begin{array}{l}\text { I am satisfied with } \\
\text { the safe working } \\
\text { condition. }\end{array}$ & $\begin{array}{l}1 \\
(4 \%)\end{array}$ & $\begin{array}{l}13 \\
(52 \%)\end{array}$ & $\begin{array}{l}0 \\
(0 \%)\end{array}$ & $\begin{array}{l}10 \\
(40 \%)\end{array}$ & $\begin{array}{l}1 \\
(0 \%)\end{array}$ & 0.12 & 0.592 & Unsatisfied \\
\hline $\begin{array}{l}\text { I am happy with my } \\
\text { work responsibilities }\end{array}$ & $\begin{array}{l}0 \\
(0 \%)\end{array}$ & $\begin{array}{l}21 \\
(84 \%)\end{array}$ & $\begin{array}{l}2 \\
(8 \%)\end{array}$ & $\begin{array}{l}2 \\
(8 \%)\end{array}$ & $\begin{array}{l}0 \\
(0 \%)\end{array}$ & 0.76 & 0.00 & Satisfied \\
\hline \multicolumn{9}{|c|}{ Satisfaction about rewards } \\
\hline $\begin{array}{l}\text { I am satisfied with } \\
\text { the existing salary } \\
\text { structure of the } \\
\text { company. }\end{array}$ & $\begin{array}{l}0 \\
(0 \%)\end{array}$ & $\begin{array}{l}7 \\
(28 \%)\end{array}$ & $\begin{array}{l}1 \\
(4 \%)\end{array}$ & $\begin{array}{l}15 \\
(60 \%)\end{array}$ & $\begin{array}{l}2 \\
(8 \%)\end{array}$ & -0.52 & 0.028 & Dissatisfied \\
\hline $\begin{array}{l}\text { I am satisfied } \\
\text { with the } \\
\text { compensation I } \\
\text { get \& I think it } \\
\text { matches with } \\
\text { my } \\
\text { responsibility }\end{array}$ & & $\begin{array}{c}7 \\
(28 \%)\end{array}$ & $\begin{array}{c}3 \\
(12 \%)\end{array}$ & $\begin{array}{c}11 \\
(44 \%)\end{array}$ & $\begin{array}{c}3 \\
(12 \%)\end{array}$ & -0.48 & 0.034 & Dissatisfied \\
\hline $\begin{array}{l}\text { I'm satisfied with the } \\
\text { incentive given }\end{array}$ & $\begin{array}{l}0 \\
(0 \%)\end{array}$ & $\begin{array}{l}10 \\
(40 \%)\end{array}$ & $\begin{array}{l}1 \\
(4 \%)\end{array}$ & $\begin{array}{l}9 \\
(36 \%)\end{array}$ & $\begin{array}{l}5 \\
(20 \%)\end{array}$ & -0.64 & 0.128 & Unsatisfied \\
\hline $\begin{array}{l}\text { I am happy with the } \\
\text { promotion }\end{array}$ & $\begin{array}{l}1 \\
(4 \%)\end{array}$ & $\begin{array}{l}12 \\
(48 \% 0\end{array}$ & $\begin{array}{l}6 \\
(24 \%)\end{array}$ & $\begin{array}{l}5 \\
(20 \%)\end{array}$ & $\begin{array}{l}1 \\
(4 \%)\end{array}$ & 0.2 & 0.375 & $\begin{array}{l}\text { Not } \\
\text { significant }\end{array}$ \\
\hline \multicolumn{9}{|c|}{ Satisfaction about the facilities } \\
\hline $\begin{array}{l}\text { I'm satisfied with } \\
\text { transport facilities } \\
\text { given by the company }\end{array}$ & $\begin{array}{l}0 \\
(0 \%)\end{array}$ & $\begin{array}{l}3 \\
(12 \%)\end{array}$ & $\begin{array}{l}0 \\
(0 \%)\end{array}$ & $\begin{array}{l}17 \\
(84 \%)\end{array}$ & $\begin{array}{l}5 \\
(20 \%)\end{array}$ & -0.04 & 0.00 & Dissatisfied \\
\hline $\begin{array}{l}\text { I'm satisfied with the } \\
\text { telephone facilities } \\
\text { given by the } \\
\text { company }\end{array}$ & $\begin{array}{l}0 \\
(0 \%)\end{array}$ & $\begin{array}{l}8 \\
(32 \%)\end{array}$ & $\begin{array}{l}0 \\
(0 \%)\end{array}$ & $\begin{array}{l}13 \\
(52 \%)\end{array}$ & $\begin{array}{l}4 \\
(16 \%)\end{array}$ & -0.48 & 0.031 & Dissatisfied \\
\hline $\begin{array}{l}\text { I'm satisfied with the } \\
\text { leaflets and } \\
\text { stationeries given by } \\
\text { the company. }\end{array}$ & $\begin{array}{l}6 \\
(24 \%)\end{array}$ & $\begin{array}{l}18 \\
(72 \%)\end{array}$ & $\begin{array}{l}0 \\
(0 \%)\end{array}$ & $\begin{array}{l}1 \\
(4 \%)\end{array}$ & $\begin{array}{l}0 \\
(0 \%)\end{array}$ & 1.16 & 0.00 & $\begin{array}{l}\text { Highly } \\
\text { satisfied }\end{array}$ \\
\hline
\end{tabular}




\begin{tabular}{|c|c|c|c|c|c|c|c|c|}
\hline \multicolumn{9}{|c|}{ Satisfaction about supervisors } \\
\hline $\begin{array}{l}\text { I am satisfied with } \\
\text { the supervisors in my } \\
\text { workplace as positive } \\
\text { role models }\end{array}$ & $\begin{array}{l}15 \\
(60 \%)\end{array}$ & $\begin{array}{l}10 \\
(40 \%)\end{array}$ & $\begin{array}{l}0 \\
(0 \%)\end{array}$ & $\begin{array}{l}0 \\
(0 \%)\end{array}$ & $\begin{array}{l}0 \\
(0 \%)\end{array}$ & 1.6 & 0.00 & $\begin{array}{l}\text { Highly } \\
\text { satisfied }\end{array}$ \\
\hline $\begin{array}{l}\text { I'm satisfied with the } \\
\text { continuous feedback } \\
\text { provide by the } \\
\text { supervisors. }\end{array}$ & $\begin{array}{l}13 \\
(52 \%)\end{array}$ & $\begin{array}{l}12 \\
48 \%)\end{array}$ & $\begin{array}{l}0 \\
(0 \%)\end{array}$ & $\begin{array}{l}0 \\
(0 \%)\end{array}$ & $\begin{array}{l}0 \\
(0 \%)\end{array}$ & 1.52 & 0.00 & $\begin{array}{l}\text { Highly } \\
\text { satisfied }\end{array}$ \\
\hline \multicolumn{9}{|c|}{ Satisfaction about job security } \\
\hline $\begin{array}{l}\text { I am happy with my } \\
\text { overall job security }\end{array}$ & $\begin{array}{l}0 \\
(0 \%)\end{array}$ & $\begin{array}{l}7 \\
(28 \%)\end{array}$ & $\begin{array}{l}3 \\
(12 \%)\end{array}$ & $\begin{array}{l}10 \\
(40 \%)\end{array}$ & $\begin{array}{l}5 \\
(20 \%)\end{array}$ & -0.48 & 0.029 & Dissatisfied \\
\hline \multicolumn{9}{|c|}{ Satisfaction about able to maintain a healthy balance between work and family life } \\
\hline $\begin{array}{l}\text { I am satisfied, able to } \\
\text { maintain a healthy } \\
\text { balance between } \\
\text { work and family life. }\end{array}$ & $\begin{array}{l}4 \\
(16 \%)\end{array}$ & $\begin{array}{l}17 \\
(68 \%)\end{array}$ & $\begin{array}{l}2 \\
(8 \%)\end{array}$ & $\begin{array}{l}2 \\
(8 \%)\end{array}$ & $\begin{array}{l}0 \\
(0 \%)\end{array}$ & 0.92 & 0.00 & Satisfied \\
\hline
\end{tabular}

case of agricultural Instructors (AIs) o the department of Agriculture in Southern Province.

\section{CONCLUSION}

It can be concluded that PDOs satisfied about their working environment, performance appraisal criteria, work responsibilities, supervisors, available teaching aids such as leaflets and stationeries as well as they have a balanced career and family life. PDOs are not in the satisfactory level about their income, fuel and telephone bill allowance and career security. Suggestions to improve job satisfaction of PDOs are increasing the basic salary, develop a proper incentive scheme, implement a system to confirm the PDOs and increase the fuel and telephone bill allowance.

\section{REFERENCE}

Brayfield AH and Rothe HF 1951 An index of job satisfaction, Journal of Applied Psychology, Vol 35(5), Oct 1951, 307-311.

Hong LH, Hamid NINA and Sallesh NM 2013 A Study on the Factors Affecting Job Satisfaction amongst Employees of a Factory in Seremban, Malaysia, Business Management Dynamics, Vol.3, No. 1.

Judge TA, Thoresen CJ, Bono JE and Patton GK 2001 The Job Satisfaction - Job Performance Relationship: A Qualitative and Quantitative Review. Psychological Bulletin, Vol. 127, No. 3, pp. 376-407.

Rollinson D, Broadfield A, and Edwards DJ 1998 Organizational Behaviour and Analysis, An Integrated Approach, Pearson Education, Prentice Hall.

Sandika AL and De Silva KNN 2012 Relationship between job satisfaction and organizational climate: The case of agricultural Instructors (AIs) o the department of Agriculture in Southern Province, Proceedings of the $8^{\text {th }}$ International Conference on Business Management, Organized by Faculty of Management Studies and Commerce, University of Sri Jayewardenepura. pp $1-8$. 